\title{
Incunabula in Communities of Canonesses Regular and Tertiaries Related to the Devotio Moderna
}

\section{Toward an Inclusive' Approach of Late Medieval Book Ownership in the Low Countries}

\author{
Anna Dlabačová | ORCID: 0000-0003-4534-5814 \\ University Lecturer, Centre for the Arts in Society, Leiden University, \\ Leiden, the Netherlands \\ a.dlabacova@hum.leidenuniv.nl \\ Patricia Stoop | ORCID: 0000-0001-8651-064X \\ University Lecturer, Department of Literature, University of Antwerp, \\ Antwerp, Belgium \\ patricia.stoop@uantwerpen.be
}

\begin{abstract}
This contribution discusses the hitherto overlooked ownership of the earliest printed books (incunabula) by Netherlandish female religious communities of tertiaries and canonesses regular connected to the religious reform movement of the Devotio moderna. Studies of book ownership and book collections in these communities have tended to focus on manuscripts. From the last decades of the fifteenth century onwards, however, these religious women increasingly came in contact with printed books, even though the involvement of the Devotio moderna with the printing press was limited. The discussion focuses on the channels via which tertiaries and canonesses acquired books produced by commercially operating printers, the ways in which incunabula affected what these (semi-)religious women read, as well as the ratio between printed books in Latin and the vernacular, and their function(s) within these communities. Thus the essay intends to sketch a preliminary image of the role of incunabula in female convents, and advocates a more inclusive approach of female religious book ownership.
\end{abstract}




\section{Keywords}

incunabula - medieval book ownership - manuscript and print - female religious communities - Devotio moderna - Low Countries

In the last decades of the fifteenth century, the printing press, and particularly its products, increasingly reached religious communities. ${ }^{1}$ Even though late medieval convent libraries are often viewed as collections of hand-written codices, their shelves became gradually filled with manuscripts and printed books alike. This essay explores the ownership of the products of the earliest presses, i.e. incunabula (books printed before 1501), in female communities in the Low Countries. In their study of Middle Dutch manuscripts from (semi-)religious communities in the Low Countries, Karl Stooker and Theo Verbeij mention the rise of the printed book: 'already at the end of the fifteenth, but especially in the sixteenth century, printed works took up a place alongside or even at the expense of the manuscripts in many communities.' ${ }^{2}$ Practical reasons, for example the lack of easily accessible inventories, however, forced Stooker and Verbeij to exclude printed books from their study and to issue a warning that their conclusions, especially with regard to the dissemination of texts, should be used cautiously. ${ }^{3}$

Our aim is to provide a preliminary survey of incunabula in communities of canonesses regular and tertiaries that pertained to, or were associated with, the Devotio moderna, the influential reform movement in the late medieval Low Countries. ${ }^{4}$ What types of works found their way into the book collections of these female religious houses in printed form? Did the introduction of the

1 On (male) monastic printing shops in Europe, see F. Eisermann, 'A Golden Age? Monastic Printing Houses in the Fifteenth Century', in: Print Culture and Peripheries in Early Modern Europe, ed. B. Rial Costas (Leiden 2013), pp. 37-67. After an initial involvement of monastic workshops in the production of printed books secular workshops clearly prevailed and the Church took on the role of consumer of printed books: 'As a consequence of the invention of printing, the majority of books no longer came from monasteries; but a considerable portion of the new books certainly found their way into the monasteries, and we should not forget that this is one of the main reasons why they still exist.' (p. 67).

2 'reeds op het eind van de vijftiende, maar vooral in de zestiende eeuw, veroverden de gedrukte werken in veel gemeenschappen een plaats naast of zelfs ten koste van de handschriften', in: K. Stooker \& T. Verbeij, Collecties op orde. Middelnederlandse handschriften uit kloosters en semi-religieuze gemeenschappen in de Nederlanden (Miscellanea Neerlandica, 15-16), 2 vols. (Leuven 1997), vol. 1, p. 3.

3 Stooker \& Verbeij, op. cit. (n. 2), p. 3 .

4 For a good, recent introduction to this reform movement, see De Moderne Devotie. Spiritualiteit en cultuur vanaf de late Middeleeuwen, ed. A. Dlabačová et al. (Zwolle 2018). 
printing press and the new dynamic of secular printing shops catering to a largely anonymous market affect the dissemination of texts in these communities? What can incunabula from female religious possession tell us about the channels of acquisition of the earliest printed books and about their mobility?

Although the direct involvement of the Devotio moderna with the printing press has not turned out to be as large as scholars expected - in the fifteenthcentury Low Countries presses in Brussels (1475-87), Gouda (c. 1486-1521), and Schoonhoven $\left(1495^{-1519)}\right.$ were run by male members of the movement (Brothers of the Common Life and canons regular) - that does not mean that incunabula produced by lay/secular printers and distributed via commercial channels passed by the houses that belonged to the circles of this influential reform movement. ${ }^{5}$ Ed van der Vlist recently demonstrated how printed books indeed formed an integral part of the book collections of male religious houses in the Low Countries toward the end of the fifteenth century. His survey of the library collection of the Carthusians in Amsterdam shows that at least eight incunabula owned by the monks are still extant. ${ }^{6}$ Thus far, however, the presence of incunabula in women's communities within the Devotio moderna has not received any specific attention. With this study, we carefully want to take the first steps to fill that gap. The essay intends to sketch a prelusive image of the role of incunabula in female convents, and intends to induce a more 'inclusive' approach of female religious book ownership in the last decades of the fifteenth century by including printed books into the analysis, and thus diminishing the dividing line between manuscript and print.

Almost twenty-five years after the publication of Stooker and Verbeij's pioneering study on monastic book collections, detailed and systematic information about provenances and late medieval and early modern ownership of incunabula, is still lacking. ${ }^{7}$ Our exploration is based on our own research projects into incunabula and late medieval female book ownership, and a survey of secondary literature, and of (online) library catalogues. Therefore, the present study is by no means exhaustive, and, as the acquisition of (printed) books in the late fifteenth century itself, to a certain extent dictated by chance. It can only reveal the proverbial tip of the iceberg. Nevertheless, the survey offers some significant indications with regard to the questions posed above. In the

5 K. Goudriaan, 'The Devotio Moderna and the Printing Press (ca. 1475-1540)', Church History and Religious Culture, 93 (2013), pp. 578-6o6.

6 E. van der Vlist, 'Middeleeuwse metadata. Boeken van de Amsterdamse kartuizers', in: Schriftgeheimen. Opstellen over schrift en schriftcultuur. Verzamelde opstellen van Nederlandse boekhistorici ter ere van Jos Biemans, ed. M. Hogenbirk \& L. Kuitert, in collaboration with P. Dijstelberge \& J. Witte (Amsterdam 2017), pp. 439-40.

7 A valuable source of information is the Material Evidence in Incunabula-database, https:// data.cerl.org (accessed 13 November 2020) that seeks to fill this lacuna. 
future, research should seek to include data about the acquisition of printed books from archival sources, such as financial accounts from female Modern Devout communities, if at all available, and take account of book lists explicitly stating the presence of printed books in these libraries. Such an exploration, however, is beyond the scope of this article.

In the following we first aim to provide a general overview and a discussion of how individual books entered a particular convent. The second and third sections focus on the texts that were disseminated in communities of tertiaries and canonesses regular in incunabula and on the ratio between books in the Dutch vernacular and Latin respectively.

\section{Printed Possessions}

In our search for incunabula from houses of tertiaries and regular canonesses related to the Devotio moderna we have encountered 85 books printed in the period between 1472 and 1 January 1501.37 of them were owned by 22 convents of canonesses regular: Amsterdam, (possibly) St Agnes (1), St Catharina (2), St Maria Magdalena op het Spui (1), and Ter Lelie (3); Beverwijk, Marienborn (1); Brussels, Onze Lieve Vrouw ter Rosen gheplant in Jericho (3); Delft, St Agnes in het dal van Josaphat (1), and St Anna (2); Deursen near Ravenstein, Soeterbeeck (2); Diepenveen, St Maria and St Agnes (3); Dordrecht, St Agnes (1); Geldern, Nazareth (1); Gent, St Agnes (1); Hoorn, Bethlehem (1); Leiden, St Cecilia (1) and Rapenburg (3); Maaseik, St Agnes (1); Moerbeke near Brugge, Sarepta (1); Oegstgeest near Leiden, Mariënpoel (3); The Hague, St Agnes (2); Utrecht, Jerusalem (2); and Venray, Jerusalem (1). The Leiden sisters of St Clara 'bij het Rapenburg' were strictly speaking not canonesses regular, but so-called 'conversinnen' of St Augustine: lay sisters associated with the Chapter of Windesheim through their confessors. ${ }^{8}$ The following 25 communities of tertiaries owned 48 incunabula in total: (possibly) Alkmaar, Jonge Hof (1); Amersfoort, St Agnes (1); Amsterdam, St Barbara (1), St Cecilia (1), St Clara (1), St Margaretha (1), and Elfduizend Maagden (4); Den Dungen near 's-Hertogenbosch, Eikendonk (1); Enkhuizen, St Clara (2); Haarlem, Crayenhorst (1), St Anna (2), St Catharina (2), and Maria Tenhemelopneming (2); Harderwijk, St Catharina (1); Heusden, St Catharina (4); Hoorn, St Catharina (1); (possibly) Leiden, St Barbara (1), and Roomburg (1); Muiden, St Catharina (1); Tongeren,

8 On this type of Augustinian sisters, see K. Goudriaan, 'De observantie der conversinnen van Sint-Augustinus', in: Monastiek observantisme en Moderne Devotie in de Noordelijke Nederlanden, ed. H. van Engen \& G. Verhoeven (Hilversum 2008), pp. 168-211 with an overview of the monasteries on pp. 209-11. 
St Agnetenberg (2); Utrecht, St Cecilia (1), St Maria Magdalena (2), and St Nicolaas (2); and Weesp, Jonge Hof (9) and Oude Hof (3). ${ }^{9}$

The text that occurs most often in our list of preserved incunabula is Dat boeck des gulden throens, the Middle Dutch translation of Die vierundzwanzig Alten oder der goldene Thron der minnenden Seele, written by the Basel Franciscan Otto of Passau (d. after 1383/86). This popular text was published twice in the Netherlands: first in Utrecht by the so-called 'Printer with the Monogram' (active 1479-1480) on 30 March 1480; the second time by Jacob Bellaert (active between $1483-86$ ) in Haarlem on 25 October $1484 .^{10}$ Six houses of canonesses regular and three communities of tertiaries owned the text; both editions occur in both branches of the Devotio moderna.

In the case of the copy owned by the canonesses of the Brussels convent of Jericho, it is clear how and when the copy (Paris, Bibliothèque nationale de France (BnF), D-2797 (2)) found its way into the convent. In the period between 15 June 1482 and the same date of the following year, Prioress Elisabeth van Poylc (d. 1499) registered that Sister Anne Jordaens (d. 1495) purchased Otto of Passau's text (in the first edition from 1480) from her brother Adam (1449-94), a canon regular in St Maartensdal in Louvain, for the price of ten schellingen: 'Item for a Middle Dutch book called the golden throne which Sister Anna Jordaens bought from her brother Adam who lived in Louvain 10 shillings.'11 Not much later, in the period between 15 June and All Saints 1483, the prioress purchased a 'studeerboeck' ('study book') for Anne's sister Griete

$9 \quad$ For a list of what each institution owned, see Appendix 1.

10 For the transmission of this text in the Low Countries, in both manuscript and early print, see A. Bouwman, 'Prozaproductie in twee kolommen. De Middelnederlandse bronnen van Otto von Passaus Die 24 Alten', in: Manuscripten en miniaturen. Studies aangeboden aan Anne S. Korteweg bij haar afscheid van de Koninklijke Bibliotheek, ed. J. Biemans et al. (Zutphen 2007), pp. 47-58; G.J. Jaspers, 'Otto von Passau in den Niederlanden', Neophilologus, 69 (1985), pp. 90-100, esp. pp. 96-7; G.J. Jaspers, 'Otto von Passau in Nederlandse handschriften', Ons Geestelijk Erf, 6o (1986), pp. 302-48; and G. Jaspers, Een Amsterdams Marialeven in 25 legenden uit handschrift 846 van Museum Amstelkring (Middeleeuwse Studies en Bronnen, 79) (Hilversum 2003), pp. 56-62. According to Jaspers (2003), copies of the Utrecht 1480 edition have also been preserved from Diepenveen (Berlin, Staatsbibliothek) and Maria Magdalena op het Spui (Louvain, Maurits Sabbebibliotheek, fonds Berchmanianum). Unfortunately, he nor the Incunabula Short Title Catalogue mention the signatures.

11 'Item voir een dietsch boeck geheeten den guldenen throen dat suster Anna Yordaens aen haeren broeder Adam cochte te Loven woenende x schellingen', Rijksarchief te Brussel, Kerkarchief/Archives ecclésiastiques du Brabant, 12.784, f. 8v. On Anne and Griete Jordaens, see P. Stoop, Schrijven in commissie. De zusters uit het Brusselse klooster Jericho en de preken van hun biechtvaders (ca. 1456-1510) (Middeleeuwse Studies en Bronnen, 127) (Hilversum 2013), pp. 107-10. 
(d. 1519), also from their brother Adam: 'Item for a study book which I bought for Sister Griete Jordaens from her brother Adam, 4 shillings 3 pennies.' ${ }^{12}$ In all probability, Elisabeth referred to the Wech der sielen salicheit (Utrecht: Printer with the Monogram, 1480) that nowadays is bound together with Dat boeck des gulden throens (Paris, BnF, D-2797 (1)). Both early printed books contain comparable rubrication, which seems to have been added already in Utrecht (the penwork in Dat boeck des gulden throens certainly stems from that region). The folio with the printer's mark in Dat boeck des gulden throens contains the following ownership inscription: 'This book belongs to the convent of Jericho and was left to us by the sisters Jordaens. Pray for them for God's [sake]' (f. cxcvij verso). ${ }^{13}$ This ownership inscription, mentioning the plural ghesusteren, seems to imply that both books, which entered the convent separately, were bound together before they were passed on to the convent, possibly after the death of Griete in $1519 .{ }^{14}$ The explicit inclusion of the purchase of incunabula in the accounts of the convent of Jericho and the survival of the very books mentioned seems to be unique. Adam Jordaens's role in procuring these incunabula is intriguing. He seems to have acted as a kind of intermediary. Unfortunately, it is unclear how he had obtained the books, but it is not unconceivable that there was a connection to a book seller in Louvain.

Other copies of Dat boeck des gulden throens were donated to convents by lay people. The canonesses regular of Jerusalem in Utrecht received their book (again a copy of the first edition) from a woman and her son: 'This book belongs to the convent of nuns in Jerusalem and came from our mother Truide and Tyman her son. Pray for them for God's sake' (Utrecht, University Library

12 'Item om een studeerboeck dat ic zuster Grietken Jordaens cochte aen haren brueder Adam iiii schellingen iii denieren', Rijksarchief te Brussel, Kerkarchief/Archives ecclésiastiques du Brabant, 12.784, f. 17r.

13 'Dit boeck hoert toe den cloester van Jhericho ende is ons bleven vanden ghesusteren Joerdaens. Bidt voer hen om gode'. See also: Corpus catalogorum Belgii. The Medieval Booklists of the Southern Low Countries, ed. A. Derolez, V. Benjamin, and W. Bracke, 7 vols. (Brussel 1994-2009), vol. 7, no. 626.

14 Given that Elisabeth van Poylc mentions two separate payments over the course of eighteen months, it is unlikely that Dat boeck des gulden throens was bound together with the Wech der sielen salicheit at the time that it entered Jericho. A copy of an earlier edition of the Wech der sielen salicheit (Utrecht: Printer with the Monogram, before 5 May 1479) was owned by the tertiaries of St Barberadaal in Den Dungen near 's-Hertogenbosch: 'Dit boeck hoert toe ten susteren te sinte Barbarendale buyten Tsertogenbosch op die Eykendonck' ['This book belongs to the sisters of St Barbaradaal outside 's-Hertogenbosch at the Eikendonk'] (The Hague, KB, KW 168 E 32, flyleaf at the front). 


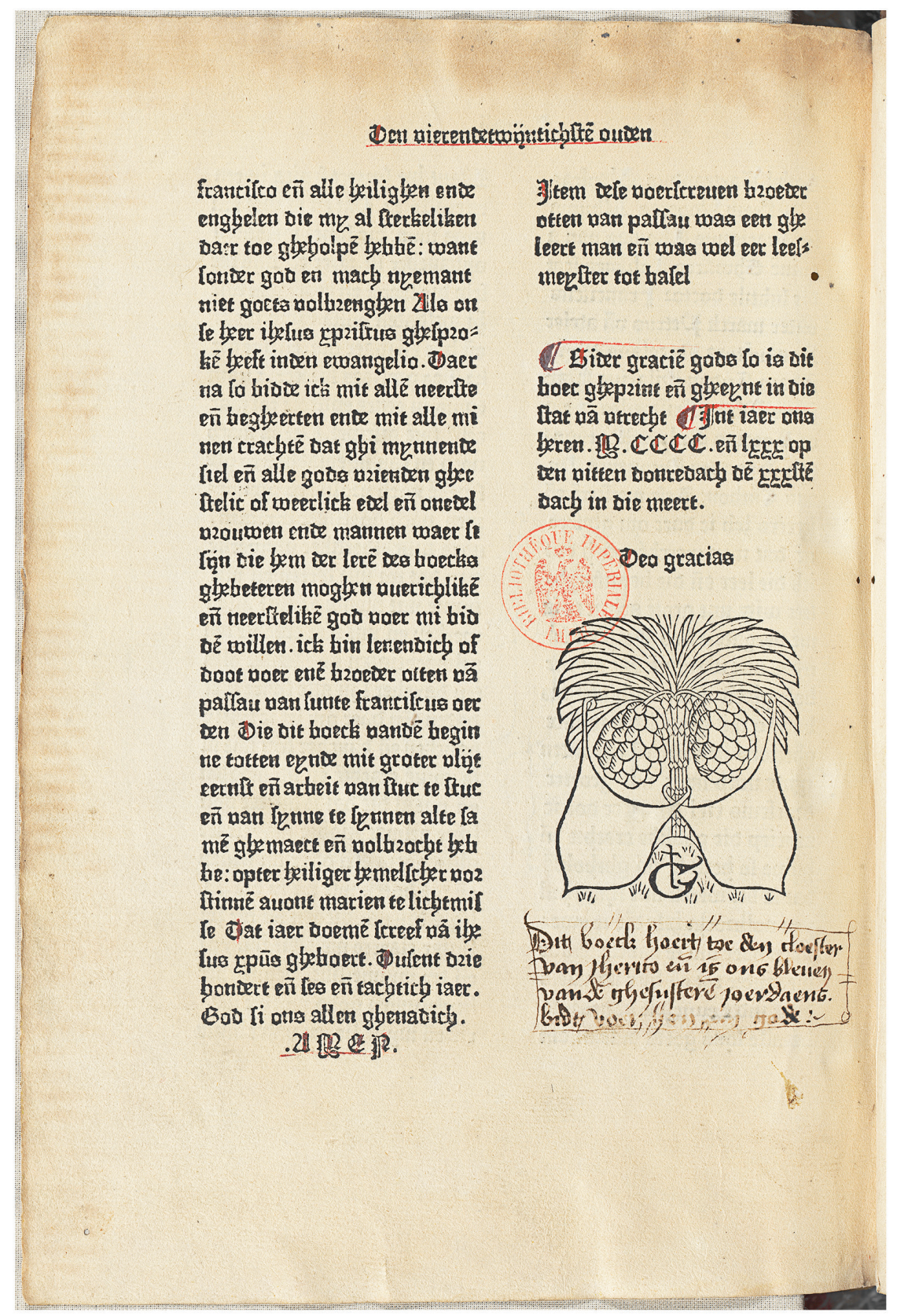

FIGURE 1 Ownership inscription of Anne and Griete Jordaens in Dat boeck des gulden throens (Paris, BnF, D-2797 (2), f. cxcvij verso) 
(UB), E fol. 153 (1), flyleaf at the front). ${ }^{15}$ The 'onse moeder' seems to imply that the woman who donated the book was not only a lay woman (she has a son), but also that she was the mother of a nun or nuns in the convent. As in the example from Jericho, this book entered the monastic institution via family relations, although in this case as a gift rather than as an acquisition the sisters paid for. ${ }^{16}$

It seems that Truide and Tyman did not only give the canonesses Dat boeck des gulden throens. This is bound together with the Wech der sielen salicheit (Utrecht: Printer with the Monogram, 1480; Utrecht, UB, E fol. 153 (2)), creating the exact same combination as in the composite volume owned by the canonesses of Jericho, but in reverse order. The Brothers of the Common Life of St Hieronymus in Utrecht, who owned a large collection of incunabula themselves, bound both books, which have the same rubrication and penwork initials in a Utrecht style, in one binding. ${ }^{17}$

15 'Dit boec hoert den convent der nonnen in Jherusalem ende is ghecomen van onse moeder Truiden ende Tyman haer soen. Daer biddet voer om gods wil', http://objects.library .uu.nl/reader/index.php?obj=1874-312354\&lan=en" |I "page//15/74/28/15742839040503833 3425609122564797707023.jpg (accessed 13 November 2020). The online catalogue of the University Library of Utrecht mentions that the incunable stems from the convent of Jerusalem in Venray. As the binding most likely was produced by the Brothers of the Common Life of St Hieronymus in Utrecht (see below), and the sisters in Venray always mentioned the location of their convent explicitly in their manuscripts (for example 'Dit boeck hoert toe den susteren van Jherusalem te Venray' ['This book belongs to the sisters of Jerusalem in Venray'] (The Hague, Кв, 133 F 22), we assume that this copy of Dat boeck des gulden throens belongs to the sisters in Utrecht, who moved to the Kromme Nieuwe Gracht within the city walls of Utrecht in 1483. See also G. Gerritsen-Geywitz, Het Utrechtse draakje en zijn entourage. Vijftien penwerkstijlen in Utrechtse handschriften en gedrukte boeken uit de tweede helft van de vijftiende eeuw (Middeleeuwse Studies en Bronnen, 168) (Hilversum 2017), pp. 88-9.

16 Manuscripts also often came into the possession of convents via family ties. See, for example, Th. de Hemptinne, 'Reading, Writing, and Devotional Practices. Lay and Religious Women and the Written Word in the Low Countries (1350-1550)', in: The Voice of Silence. Women's Literacy in a Men's Church, ed. Th de Hemptinne \& M.E. Góngora (Medieval Church Studies, 9) (Turnhout 2004), pp. 122-6; and P. Stoop, 'The Brussels Convent of Jericho and its Literary Network / El convent do Jericó en Bruselas y su red literaria', Anuario de estudios medievales, 44.1 (2014), pp. 381-412.

17 http://objects.library.uu.nl/reader/index.php?obj=187431283o\&lan=en\#page//12/57 / 78/125778831804862253842131851549309775386.jpg/mode/1up and https://objects.library .uu.nl/reader/index.php?obj=1874-312354\&lan=en\#page $/ / 16 / 26 / 48 / 162648$ $632823087661061024182333764817819 . j p g / m o d e / 1 u p ~(a c c e s s e d ~ 13$ November 2020). For the style dominant in the Boeck des gulden throens, Gisela Gerritsen-Geywitz has coined the term 'Thick nose'-style. See Gerritsen-Geywitz, op. cit. (n. 15), pp. 88-9. The University Library of Utrecht still owns twenty-seven incunabula from the Brothers' library. See: K. van 
Another male bookbinder from an unidentified religious community was responsible for binding a copy of the second, Haarlem edition of Dat boeck des gulden throens, owned by the canonesses regular of St Anna in Delft (Wolfenbüttel, $\mathrm{HAB}, \mathrm{A}: 5^{23.1}$ Theol. $2^{\circ}(2)$ ). It was bound together with a copy of Der sielen troest, published by Jacob Bellaert less than three months before Dat boeck des gulden throens, on 9 August 1484. The note beneath the printer's mark at the end of Dat boeck des gulden throens (f. rgv) states that the book was bound by 'brother Dirck van Alcmaer'.18

The tertiaries of the convent of Maria Tenhemelopneming in Haarlem inherited their copy of Dat boeck des gulden throens, in the second edition printed by Jacob Bellaert, from Pieternel Direcksdochter and Marytgen Maertensdochter: 'Sisters of the convent of St Maria within Haarlem in St Jansstraat. Pieternel Direcksdochter and Marytgen Maertensdochter have given it to our sisters by way of testament' (Oxford, Bodleian Library (BodL), Auct. 6Q 5.23, f. rgr). ${ }^{19}$ Moreover, Pieternel and Marytgen also bestowed a copy of the first edition of the Boeck vanden leven Jhesu Christi (Antwerp: Gerard Leeu, 1487), a dialogic recension in Middle Dutch of the Vita Christi by Ludolph of Saxony, to their convent's library: 'This book belongs to the sisters of the convent of St Maria in Haarlem in St Jansstraat [different hand] and has been given by Pieternel Dirckdochter and Marytgen Maertensdochter to our sisters by way of testament' (The Hague, Museum Meermanno-Westreenianum (MMW), oo1 B oo2,

der Horst et al., Handschriften en Oude Drukken van de Utrechtse Universiteitsbibliotheek (Utrecht 1984), p. 99.

18 'Dit boeck hoort tot die regulierissen van sinte Annen cloester' ['This book belongs to the canonesses regular of St Anna's cloister] (flyleaf at the front); 'Item Broer Dirck van Alcmaer heeft myn ghebonden' ['Item Brother Dirck van Alkmaar has bound me'].

19 'Susteren van sinte Marien convent binnen Haerlem in sinte Jans straet ende heeft ghegeven Pieternel Direcksdochter ende Marytgen Maertensdochter onse susteren tot een testament'. Although Pieternel and Marytgen cannot be identified, it is altogether possible that they were inhabitants of Maria Tenhemelopneming. The digital Monasticon Trajectense strikingly shows that the last names of the tertiaries in the Haarlem convent end in all cases but one with the suffix -dochter (-daughter) (see https://www2.fgw.vu.nl/ $\mathrm{oz} /$ monasticon/detail.php?ID=080 [accessed 13 November 2020]). As this apparently was a conscious choice - women's last names more often ended at this suffix, but seldom as systematically as in this house - it seems possible that we should read the 'our sisters' (in this ownership inscription as well as in the next one) as 'sisters of our community' and that they bequeathed the Otto of Passau's book to the convent in which they spent their lives. In that case, this ownership inscription should be translated as 'Sisters of the convent of St Maria within Haarlem in Sint-Jansstraat. Pieternel Direcksdochter and Marytgen Maertensdochter, our sisters, have given it by way of testament']. 
f. oo6r). ${ }^{20}$ The change in hands seems to indicate that the book was indeed already in common use in the convent before the sisters' demise. A sixteenthcentury note beneath the colophon of another copy of the same edition indicates that the Boeck vanden leven Jhesu Christi was also in common use in the Brussels convent of Anne and Griete Jordaens: 'This book belongs to the monastery of Jericho at Brussels in the common library' (Paris, BnF, D-672, f. oo6r).$^{21}$ It is unclear how the book made its way into the library, but before it was placed there, the sisters inserted a penwork initial on folio a6r in a style typical of the Jericho convent, which can also be found in the manuscripts produced by the women. By adding the initial the sisters incorporated the book printed by a commercially operating lay printer in Antwerp into their own manuscript/book collection.

An unknown benefactor gave the sister of an unidentified female convent, Berbele Sthonts, a copy of the same edition of the Boeck vanden leven Jhesu Christi for shared use by the sisters of her convent (Mettingen, Draiflessen Collection, Liberna Inc 22). The intended use could not have been clearer: Berbele requested that the book should be always kept in the convent's church for sisters with a devotion to Christ's life to read on Sundays and Holy days:

I, Sister Berbele Sthonts, have received this book for our sisters in common. Begging our reverend mother that it may always lie in the church so that on Sundays and Holy Days the sisters, who have love and devotion to the precious life of our dear Lord may read from it. Pray for me (f. oo6r). ${ }^{22}$

Other incunabula were also offered by individual canonesses and tertiaries for communal use: Sister Delyaen Pauwen, for example, gave a copy of the Psalter in Dutch (The Hague, Koninklijke Bibliotheek (Кв), KW 151 D 13), printed in Delft in 1498 , for collective use in her tertiary community of St Cecilia in Utrecht. ${ }^{23}$

20 'Dit boec hoert toe den susteren van sinte Marien convent binnen Haerlem in sinte Jansstraet [different hand] ende heeft ghegeven Pieternel Dirckdochter ende Marytgen Maertensdochter onse susteren tot een testement'. See also A. Dlabačová, 'Drukken en publieksgroepen. Productie en receptie van gedrukte Middelnederlandse meditatieve Levens van Jezus (ca. 1479-1540)', Ons Geestelijk Erf, 79 (2008), p. 342.

21 'Desen bock hoert toe den closter van Jhericho tot Brussel in die ghemeyn liberye'.

22 'Ic, suster Berbele Sthonts, hebbe desen boec ghecreghen voer ons susteren int ghemeyne. Biddende onser eerweerdegher mater dat hi altoes inder kercken mach ligghen op dat die susteren des sondaechs ende des heylichs daeghs moeghen uut lesen die minne ende devocie hebben tot dat werdich leven ons liefs heren. Bidt voer mi'.

23 'Item desen souter geeft suster Delyaen Pauwen int gemeen' ['Item this psalter has given Sister Delyaen Pauwen for common use']. Next line: 'tUtrecht sinte Cecilien convent' ['In Utrecht in St Cecilia's convent']. 


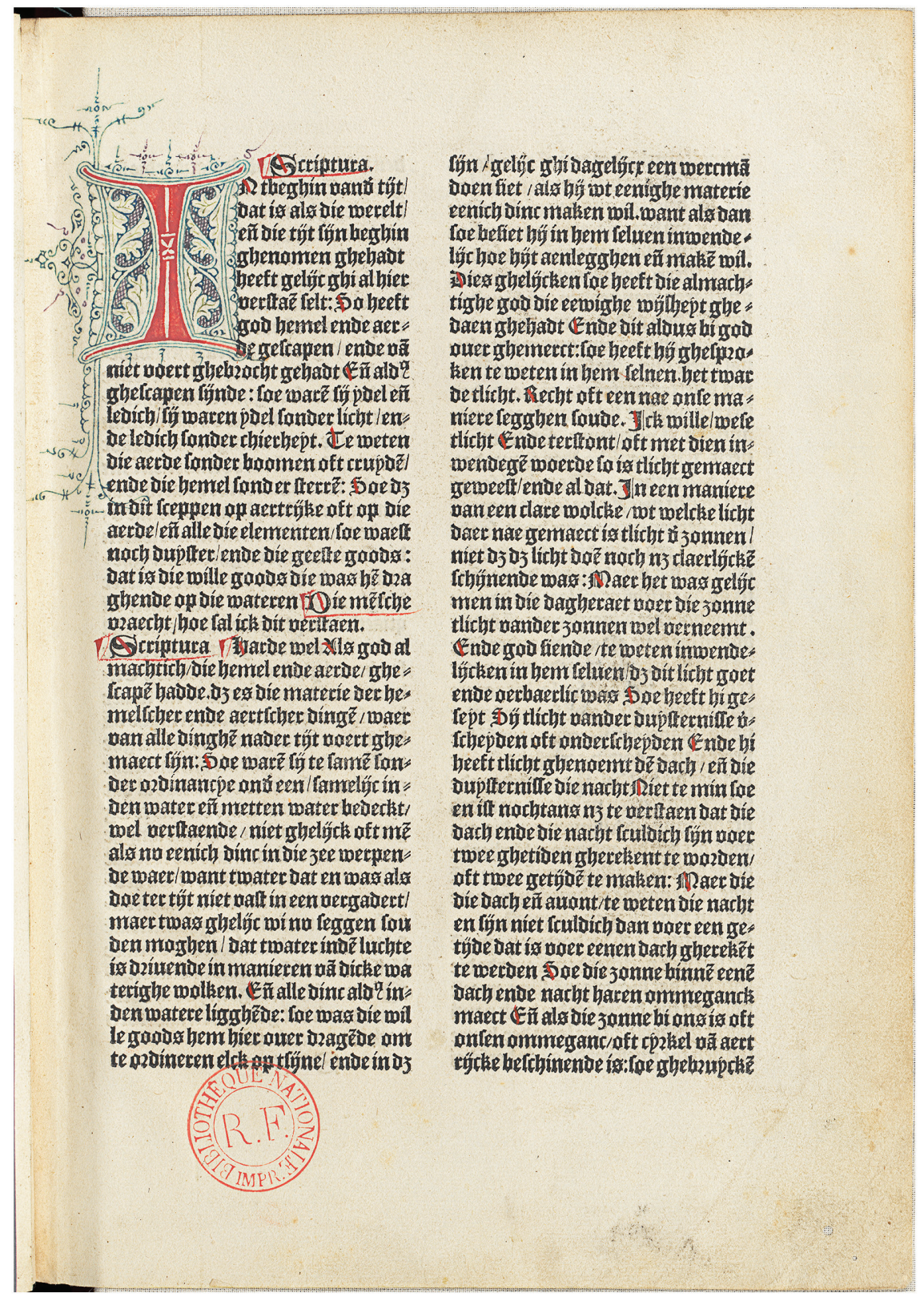

FIGURE 2 Penwork initial added to the Boeck vanden leven Jhesu Christi by the sisters at Jericho in Brussels (Paris, BnF, D-672, f. a6r) 


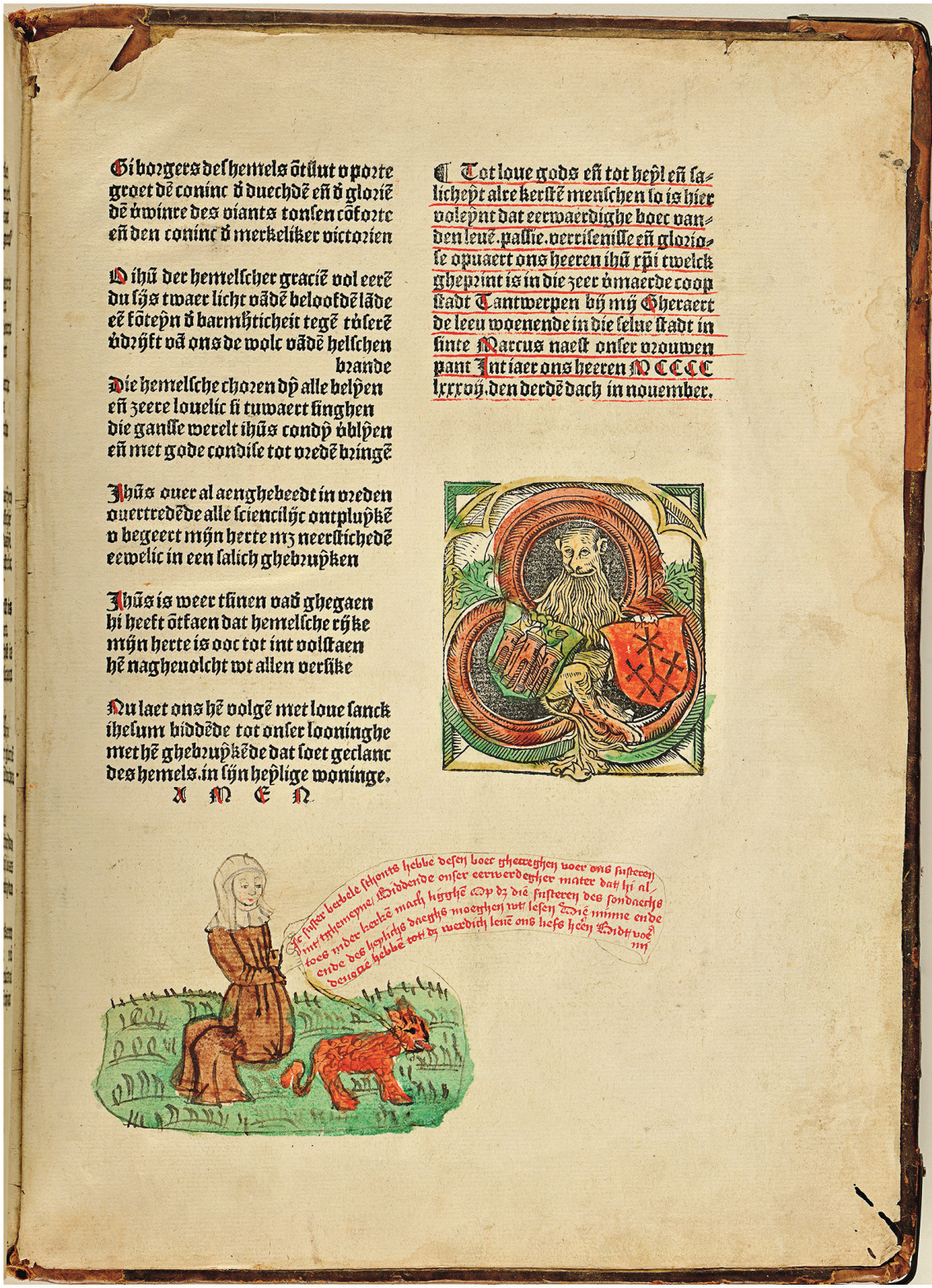

FIGURE 3 Ownership inscription and portrait of Berbele Sthonts, from Ludolphus de Saxonia, Tboekvanden leven ons heeren Jhesu Christi (Antwerp: Gerard Leeu, O3.11.1487)

(C) DRAIFLESSEN COLLECTION (LIBERNA), METTINGEN INC 22, F. OO6R (PHOTO: STEPHAN KUBE, GREVEN). 
Dierck Gherijtsdochter's copy of the Tafelboec - an extract from the Tafel van den kersten ghelove by Dirc van Delf $\left(c .1365^{-1404}\right)$ turned into a weekly exercise and published in Utrecht by the Printer with the Monogram around 1479/80 was placed in the common library of her convent of St Anna in Haarlem. ${ }^{24}$ Beatrix Catrin Dirxdochter enriched the library of the canonesses regular of St Catharina in Amsterdam with a copy of the Legenda aurea (Passionael), issued by Gerard Leeu in 1478 (Paris, BnF, RES-H-271). ${ }^{25}$ The Haarlem tertiaries of St Anna who owned the Tafelboec also had a Passionael at their disposal, but their copy was of Leeu's second, 1480 edition (Oxford, BodL, Auct. III.Q.V.29). This book does not seem to have entered the convent through a specific sister. ${ }^{26}$ The ownership inscription does not specify how the book was acquired, which is actually the case in the majority of incunabula in the possession of canonesses regular and tertiaries.

How Berbele, Delyaen, Dierck, and Beatrix acquired the incunabula that they donated for common use is unclear. A family member might well have given these books to them. Apart from parents - see the case of mother Truide and her son Tyman above - godmothers and uncles also bequeathed printed books to tertiaries. The Amsterdam tertiaries of Elfduizend Maagden, who owned a copy of the Haarlem edition of Otto of Passau's work, received a copy of the Van den leven der heiligen vaderen (Dat vader boeck), the Middle Dutch translation of the Vitas patrum, published by Gerard Leeu in 148o, from Sister Dieue Aelberts' godmother. According to the ownerships inscription, she passed away in 1530 on the day after the feast the beheading of St John the Baptist (25 June). The different hands in, and alterations to, the note, suggest that the annotation was altered after Dieue's godmother died. ${ }^{27}$ This may have

24 Haarlem, SB, 56 D 19, ff. 1r and 119v: 'Item dit boeck hoert Dierck Gherijtsdochter toe, een zuster tot Sinte Anna conventh ende is gheordineert in die ghemiene boecken des [convenths]' ['Item this book belongs to Dierck Gherijtsdochter, a sister in the convent of Sint-Anna, and is arranged between the convent's common books'].

25 'Item dit boec hoert totten bescloten nonnen en ende [!] regulierissen van sancta Katerina binnen Amstelredam. Dit boec is ghecomen van Becratrix [Beatrix] Cktrin [Catrin] Drixdr [!], onse stuster [!]' ['Item this book belongs to the enclosed nuns and the canonesses regular of St Catharina in Amsterdam. This book has come from Beatrix Catrin Dirxdochter, our sister']. See also L. Hellinga, 'De betekenis van Gheraert Leeu', in: K. Goudriaan et al., Een drukker zoekt publiek. Gheraert Leeu te Gouda 1477-1484 (Delft 1993), p. 28.

26 The note in this copy simply reads 'Dit boec hoert tot den susteren van Sinte Annen convent binnen Haerlem' ['This book belongs to the sisters of the convent of St Anna in Haarlem'] (fol Aiv). See https://data.cerl.org/mei/oo2o6998 (accessed 13 November 2020).

27 'Dit boeck hoert toe [change of hand] den susteren van den xidusent machden binnen Amstelredam ende is ghecomen van Dieue Aelberts petemoey die ghestorven is int jaer ons heren dusent vijfhondert ende Xxx daechs na sancte Jans onthoudinghes dach' ['This book belongs to the sisters of Elfduizend Maagden in Amsterdam, and has come from 
happened by way of commemoration, but it is also possible that the book only entered the Amsterdam community after the godmother's demise, after which her note was changed by the tertiaries. The same binding, contemporary to the books but with a restored spine, also holds a copy of the Dutch translation of the Dialogus creaturarum, the Twispraec der creaturen (Gouda: Gerard Leeu, 1481).

The great uncle of Katrijn Claes Vranckendochter, inhabitant of the Leiden tertiary convent of Roomburg, was Jan Philipszoon, city clerk in the same city and compiler of a varied collection of versified texts in manuscript (between 1472 and 1481). ${ }^{28}$ Around the time of his death in 1509, he donated a copy of the same edition of the Dutch version of the Vitas patrum owned by Elfduizend maagden in Amsterdam. Similarly to the canonesses regular of Jerusalem in Utrecht, who denoted Trude as 'our mother', the note by the Leiden tertiaries indicates Jan Philipszoon as 'our uncle': 'This book belongs to Johannes Philipzsoon our uncle, secretary of the city of Leiden, and has given it by way of testament to the sisters of St Margareta on Roomburg' (Paris, Fondation Custodia, ов-0.11.6). ${ }^{29}$ Some incunabula thus only reached tertiaries and regular canonesses after they had lived a life in the hands of lay readers. ${ }^{30}$

Dieue Aelberts' godmother who passed away in 1530 on the day after St John's beheading'] (The Hague, кв, KW 170 E 26:1, flyleaf at the front). See https://archive.org/details/nedkbn-all-oooo1917-oo1/page/ng/mode/2up (accessed 13 November 2020).

28 See H. Brinkman, Het handschrift-Jan Phillipsz. Hs. Berlijn, Staatsbibliothek Preußischer Kulturbesitz, Germ. Qu. 557 (Middeleeuwse Verzamelhandschriften uit de Nederlanden, 2) (Hilversum 1995); H. Brinkman, Dichten uit liefde. Literatuur in Leiden aan het einde van de middeleeuwen (Middeleeuwse Studies en Bronnen, 53) (Hilversum 1997). On Roomburg, see M. van Luijk, 'De tweede religieuze vrouwenbeweging te Leiden. Het convent van Sint-Margaretha of Roomburg', Ons Geestelijk Erf, 74 (2000), 50-67.

29 'Dit boeck hoort toe Johannes Philipszoon onse oem, secretarius der steden van Leyden, ende heefttet ghegeven tot enen testament den susteren sancta Margrieten op Rodenburch'. This copy is excellently introduced by H. van der Linden, 'A Little Known Copy of Vanden leven der heiligher vaderen (Gouda: Leeu, 1480) with Early Dutch Provenances', Gutenberg-Jahrbuch, 92 (2017), pp. 53-63.

30 It is not clear in all cases whether these lay readers had family ties to the religious communities to which they donated books. Aef Jan Hannesdochter left her copy of Der bien boeck by Thomas of Cantimpré (1201-c. 1272) after her death to the tertiaries of St Catharina in Hoorn (New Haven, Conneticut, Yale University Library, Beinecke 1973+12); it is only known from a seventeenth-century note that she came from a wealthy family in Wijdenes, a small village located some nine kilometers east of Hoorn. See J.M.M. Hermans, Zwolse boeken voor een markt zonder grenzen 1477-1523 ('t Goy-Houten 2005), p. 151. Copies of Der bien boeck also have been preserved from a convent of St Maria in Nazareth (possibly Jonge Hof in Alkmaar) and from the tertiaries of St Clara in Enkhuizen. This latter copy is bound together with the Haarlem 1484 edition of Dat boeck des gulden throens (Louvain, Maurits Sabbebibliotheek, Fonds Berchmanianum, 6ooo A 27 (1-2)). 


\section{Manuscript, Print, and the Dissemination of Texts}

Jan Philipszoon did not only give an incunable to his niece's tertiary convent. He also left the women a manuscript, written c. 1465, with the Pseudo-Eusebian Epistola de morte Hieronymi and the Pseudo-Augustinian Epistola de magnificentiis beati Hieronymi in Middle Dutch (the so-called Sinte Jheronimus sterfboeck; Leiden, Uв, ВPL 226o, f. 1v). ${ }^{31}$ The manuscript was given to his niece, Katrijn Claes Vranckendochter, as is clear from her ownership inscription on f. 2v: 'This book belongs to Katrijn Claes Vranckendochter in Roomburg'. ${ }^{32}$ Another manuscript (Utrecht, Museum Catharijneconvent (MCC), BMH h94) owned by the Roomburg tertiaries, and more specifically Katrijn Claes Vranckendochter, is thought to have been used to correct the copy for the edition of the Vertroostinghe der gelatenre menschen, published by the local printer Hugo Janszoon van Woerden in $1502 .{ }^{33}$ The book collection of the Roomburg tertiaries, and Katrijn in particular, is a telling example of how manuscripts and printed books were used alongside one another, how book culture in the early sixteenth century diversified, and how both media influenced one another. That raises the question how printed books affected the presence of books and texts in communities of regular canonesses and tertiaries. What was the ratio between manuscripts and printed books? Did incunabula bring new texts to existing libraries?

While some incunabula were incorporated into substantial manuscript libraries - for example of the regular canonesses in Jericho (30 manuscripts from before 1510), Diepenveen (32), St Agnes in Maaseik (84), and Nazareth in Geldern (40) $-^{34}$ the introduction of others significantly increased the number of books available in a convent. In some communities, such as the tertiaries of

31 Another niece, Margriete Claesdochter, a lay woman, received a handwritten Book of Hours (c. 1481) from her uncle (Leiden, UB, BPL 2782).

32 'Dit boeck behoert tot Katrijn Claes Vranckendochter op Roemburch'.

33 See B.J.M. de Bont, 'Een handschrift uit het klooster Roemburch bij Leiden. "Die troestinghe der ghelatenre menschen"', Bijdragen voor de Geschiedenis van het Bisdom Haarlem, 27 (1903), p. 266; De vijfhonderdste verjaring van de boekdrukkunst in de Nederlanden, ed. Claudine Lemaire et al. (Brussel 1973), pp. 11-12 (cat. no. 7); Stad van boeken. Handschrift en druk in Leiden, 1260-200o, ed. A. Bouwman (Leiden 2008), p. 92; Th. Mertens, 'De invloed van de werken van Hendrik Mande', in: Moderne devotie, figuren en facetten. Tentoonstelling ter herdenking van het sterfjaar van Geert Grote, 1384-1984. Catalogus, ed. A.J. Geurts (Nijmegen 1984), p. 196. See also Van der Linden, op. cit. (n. 29), p. 58.

34 For the book collection from Jericho, see Stoop, op. cit (n. 11), pp. 371-419. The other numbers are taken from the online Bibliotheca Neerlandica Manuscripta, https://bnm-i.huy gens.knaw.nl/ (accessed 13 November 2020). 
Maria Tenhemelopneming (2),35 and St Anna in Haarlem (2), and the canonesses regular of Jerusalem in Utrecht (1) the number of extant books is doubled by the incunabula that we were able to trace. In some cases, incunabula are even the only kind of extant book(s) with religious works from a convent (for example the tertiaries of St Nicolaas in Utrecht). ${ }^{36}$ The 'impact' of incunabula in this sense, with regard to the numbers of books owned alone and based on the material presented in this article, seems to have been largest in communities of tertiaries. In general, they owned fewer manuscripts and in their acquisition of printed books they seem to surpass the canonesses regular.

Nevertheless, even incunabula that entered into a larger collection could have a significant impact on the dissemination and availability of texts. Texts such as Otto of Passau's Boeck des gulden throens and the Wech der sielen salicheit were already available in manuscript in the Low Countries, but their dissemination was rather limited: (parts of) the latter text are contained in seven extant manuscripts and three manuscripts (of which the oldest dates to 1448) contain the full text of the Boeck des gulden throens independent of the printed editions. ${ }^{37}$ At least five manuscripts of the Boeck des gulden throens, however, are in fact copies from the incunabula editions. ${ }^{38}$ Other texts, such as the dialogue between Man and Lady Scripture in the Boeck vanden leven Jhesu Christi or the Dutch recension of the Dialogus creaturarum, did apparently not circulate at all in manuscript before they were published in print. ${ }^{39}$ The relatively recent translation of Thomas of Cantimprés Bonum universale de apibus (1451), on the other hand, seems to have already been popular in handwritten form amongst religious females in the Northern Low Countries and tertiaries

35 The name Maria Tenhemelopneming is taken from the online 'Kloosterlijst', https:// www2.fgw.vu.nl/oz/kloosterlijst/kdetails.php?ID=H22 (accessed 13 November 2020). In the scholarly literature the convent is often mentioned as Maria Visitatie. In the online Bibliotheca Neerlandica Manuscripta it is simply mentioned as St Maria, https://bnm-i .huygens.knaw.nl/lexicontermen/LEXIoooooooo4917 (accessed 13 November 2020).

36 The convent owned the Spiegel des kersten gheloefs and the Tafel des Kersteliken levens, both printed by Gerard Leeu in Gouda in 1478. Furthermore, only a convent chronicle in manuscript can be linked to the sisters of St Nicolaas: see Van der Horst, op. cit. (n. 17), p. 109 .

37 The numbers of the Wech der sielen salicheit are taken from the Bibliotheca Neerlandica Manuscripta, https://bnm-i.huygens.knaw.nl/ (accessed 13 November 2020). On the Wech der sielen salicheit, see G. Warnar, 'Wech der sielen salicheit', Dictionnaire de spiritualité, 16 (1994), col. 1338 and K. Pansters, De kardinale deugden in de Lage Landen, 1200-1500 (Hilversum 2007), pp. 96-8.

38 Bouwman, op. cit. (n. 10), pp. 49-5o.

39 Other 'new' texts include the Spiegel des kersten gheloefs and the Tafel des Kersteliken levens owned by the Utrecht tertiaries of St Nicolaas. 
in particular. The surviving copies of the 1488 edition by Peter van Os suggest a continuation of this trend. ${ }^{40}$

Even works that were well-known and represented in ample numbers among fifteenth-century manuscripts owned by various communities of canonesses regular and tertiaries, were still in demand in print, even if the printed books did not immediately replace older manuscripts. The Dutch translation of Jacobus of Voragine's Legenda aurea, the so-called Passionael, is a good example. Our investigation yielded four copies of three different editions owned by canonesses regular and tertiaries. In a copy of the second edition of the Passionael (Gouda: Gerard Leeu, 1480), nowadays in the national library of France in Paris, about ten Saints such as Odilia, Victoria, Basiulius, and Concordius are added to the table of contents (written in the margin). Below the table of contents, the same person added the following instruction: 'The [ones] that are written here, search in the old passionael' (Paris, BnF, RES-H-172). ${ }^{41}$ The 'old passionael' was likely a manuscript of the Dutch translation of Voragine's Legenda aurea, which implies that this book was added to a (convent) library, and that (older) manuscript copies remained in use once printed recensions started to become available. Unfortunately, the copy has no ownership inscription, but the handwritten reading instructions in the Dutch vernacular, and clearly directed at a fellow user of the book collection, suggest that the book was owned by a (female) religious community. The penwork initials have been added in a style typical of Haarlem, which might point to reception in that city.

\section{Latin versus Middle Dutch}

The incunabula owned by women's institutions linked to the Devotio moderna also shed light on another aspect of the medieval library collections from convents of tertiaries and canonesses regular that has been understudied thus far: the share of Latin books in them. As a result of the focus of previous research on the Middle Dutch manuscripts from religious institutions in the Low Countries, it is unclear to what extent religious women had access to devotional texts in the language that is mostly considered to be reserved for men. Of the 32 manuscripts from Diepenveen, for example, at least five are written

\footnotetext{
40 Stooker \& Verbeij, op. cit. (n. 2), p. 221, p. 276, p. 302. C.M. Stutvoet-Joanknecht, Der byen boeck. De Middelnederlandse vertalingen van Bonum universale de apibus van Thomas van Cantimpré en hun achtergrond (Amsterdam 1990), p. 13 .

41 'Dese die hier gheteikent sijn soect int oude passionael'.
} 
(or contain texts) in Latin. Our list of 85 incunabula shows that the share of Latin volumes in female houses was fairly substantial: no fewer than $32(38 \%)$ were printed in that language. Interestingly, the tertiaries owned almost as many Latin (22) as Middle Dutch books (26), whereas the canonesses regular possessed 27 Middle Dutch incunabula and only 10 in Latin.

Obviously, the books in Middle Dutch were all published in the important printing centres in the Low Countries: Antwerp (Claes Leeu and Geraert Leeu), Delft (Hendrik Eckert van Homberch, Jacob Jacobszoon van der Meer, and Christiaen Snellaert), Gouda (Geraert Leeu), Haarlem (Jacob Bellaert), Leiden (Hugo Janszoon van Woerden), Utrecht (Printer with the Monogram), and Zwolle (Peter van Os). Ten of the Latin incunabula were printed in the Netherlands as well. In a number of cases, these books were related to the liturgy of the Chapter of Windesheim, such as the Breviarium Windeshemense that belonged to the canonesses regular of Ter Lelie in Amsterdam (The Hague, Kв, KW 234 F 26); and the Breviarium Windeshemense and the Book of Hours that were owned by the canonesses of Soeterbeeck (Nijmegen, UB, IV $5^{1}$ and IV 136). The Breviarium Trajectense that belonged to the tertiaries of St Catharina in Harderwijk (The Hague, KB, KW 150 E 29) followed the liturgy of the Chapter of Utrecht. Others, such as the Consolatio Philosophiae, printed in Ghent in 1485 by Arend de Keysere (d. 1490), or Liber bibliae moralis and the Quadragesimale: sertum fidea by the Dominican preacher Leonardo Mattei da Udine (c. 1399-1469), printed respectively in 1477 and 1479-80 by Richardus Pafraet (c. 1455-1512) in Deventer, could be distributed to a larger, European market.

Conversely, it is not unexpected that books that were printed in other regions in Europe found their way to the Low Countries. With six incunabula from the period between 1472 and 1484, the prolific and nearby printing centre of Cologne is best represented in our list; other books came from Strassburg (3), Nuremberg (2), Basel (3), and Venice (1). Interestingly, the Latin books in our corpus show a vast diversity: all of them are single copies of different texts. The printed books in Dutch owned by tertiaries and canonesses regular, on the other hand, are often copies of the same text: sometimes of one edition, for example Thomas of Cantimprés Bien boec (3 copies); more often, however, they occurred in two or three editions. Cases in point are the already extensively mentioned Boeck des gulden throens (10 copies of two editions), the Boeck vanden leven Jhesu Christi, printed on 3 November 1487 by Gerard Leeu in Antwerp and a year later, on 20 November 1488, by his brother Claes (4 copies), and Die duytsche Souter, which was printed in 1480, 1487, and 1498 in Delft, by Jacob Jacobszoon van der Meer and/or Christiaen Snellaert (3 copies). Some of these texts clearly found their way to several religious communities and can be considered best-sellers. 
Although our list reveals that some of the convents possessed incunabula in the vernacular only and others only Latin ones - the role of coincidence should not be underestimated here - the surviving books of the canonesses regular of Ter Lelie, the tertiaries of Elfduizend Maagden in Amsterdam, and the canonesses regular of Diepenveen show that both languages functioned alongside one another within female communities. The extant books from the last convent seem to indicate, however, that language had consequences for who would use the books. The Liber Bibliae moralis by the Benedictine author Petrus Berchorius (c. 1290-1362), printed by Richard Pafraet in Deventer in 1477, according to its ownership inscription belonged to the Diepenveen community in general: 'This book belongs to Diepenveen' (Deventer, Athenaeumbibliotheek (АВ), $2000 \mathrm{E} 53 \mathrm{KL}$, first flyleaf at the front). ${ }^{42}$ The same applies to the post-incunable that contains the Rosetum exercitiorum spiritualium by Jan Mombaer (1460-1501) that was printed in Paris by Jean Petit and Jean Scabelerius on 13 August 1510: 'In Diepenveen near Deventer in the order of Augustinian canonesses regular' (Deventer, $\mathrm{AB}, 113 \mathrm{~B} 8 \mathrm{KL}$, second parchment flyleaf at the front). ${ }^{43}$ The ownership inscriptions of the two incunabula with Middle Dutch translations of Jacob of Voragine's Sermonen op die evangelien van de zondagen door dat gehele jaer and Otto of Passau's Boeck des gulden throens, however, specifically mention that the books belonged to the 'external sisters' or 'the sisters outside the enclosure', i.e. the lay sisters. ${ }^{44}$ Thus, the extant printed books brought together in the present study indicate that the reading of Latin was reserved for the professed canonesses and that there was a difference in the level of literacy between groups in the community, which also may reflect differences in social class between the sisters.

42 'Pertinet in Dyepeveen'. According to two other ownership inscriptions at the same flyleaf, the book at some point in time also belonged to the Crosiers in Emmerich. A third note mentions 'Yserloe', which is the name of a small hamlet in the Achterhoek in Gelderland. Whether this is also the name of a person, or refers to the court of the Lords of Anholt is unclear. See Suzan Folkerts, 'Een derde exemplaar van Deventers eersteling in de Athenaeumbibliotheek. De verspreiding van de Liber Bibliae moralis, gedrukt in 1477 door Richard Pafraet', in: Oude boeken, nieuwe podia. Liber amicorum voor Marieke van Delft / Old Books New Platforms: Liber amicorum for Marieke van Delft, ed. Jan Bos et al., (Den Haag 2021), pp 116-22.

43 'In Diepenveen prope Daventriam ordinis regularissarum augustini'.

44 'buten susteren'; 'den susteren buten dat besloot'. See, respectively, the note glued onto the verso side of the title page of Deventer, AB, 113 B 7 KL (Jacobus of Voragine): 'Dyt boeck hoert toe den buten buten [!] susteren van Diepenven' ['This book belongs to the external sisters of Diepenveen'] and the flyleaf at the front of Deventer, AB, 113 B $6 \mathrm{KL}$ (Otto of Passau): 'Item dit boeck hoert int cloester to Diepenveen. Welck ghegeven is den susteren buten dat besloot van bruder Willem dat sy god voer hem bidden sullen' ['Item this book belongs tot he convent of Diepenveen. It is given to the sisters outside the enclosure by brother Willem so that they will pray for him to God'] (flyleaf at the front). 
Other indications about who was using Latin books can be found in the incunabula from the Jonge Hof in Weesp. Quite exceptionally we know of nine extant books from this convent of tertiaries, all of them printed in Latin. Six of them have ownership inscriptions that very generally point to the convent: 'Book of the convent of St Maria in Weesp' (for example, The Hague, кв, KW 168 B 33) or 'Book of the convent of the young sisters of St Maria in Weesp' (The Hague, KB, KW 169 B 25). ${ }^{45}$ In two books, one with the Glossa magistralis Psalterii by Peter Lombard (c. 1100-116o) (The Hague, KB, KW 169 A 13), and one with the second part of the Summa theologiae by Thomas Aquinas (1225-1274) (The Hague, KB, KW $170 \mathrm{~A} 10$ ), the ownership inscription mentions that they were 'for the use of the confessor. 46 Thus the books were clearly used for the spiritual care of the women in the community. The same applied to the composite volume with Augustine's De civitate Dei and De trinitate (Basel: Johann Amerbach, 1490), which was used by Simon Wilhelm Castricum, priest and confessor in the convent of canonesses regular of St Agnes in The Hague, in 1521 (Haarlem, Stadsbibliotheek (sB), 183 C $9(1-2)) .{ }^{47}$ At first glance it seems that the confessors possessed theological treatises or glossaries in Latin that could help them to explain Scripture, whereas professed women had access to Latin texts with a more devotional and didactic character that facilitated individual study and meditation. Further research, however, is needed to get firmer ideas of what types of books - manuscripts as well as early printed books were intended for which groups within female monastic houses.

'Liber conventus sancte Marie in Weesp'; 'Liber conventus iuniorum sororum beate sancte Marie in Weesp'. The ownership inscriptions in The Hague, KB, KW 169 A 24 f. Viov, interestingly tells us that the Summa de casibus conscientiae by the Franciscan canon lawyer and theologian Astesanus of Asti (d. c. 1330) (Strassburg: Printer of Henricus Ariminensis (Georg Reyser?), not after 9 May 1474) was bound by Gerard van Buren, carthusian in St Salvator/Nieuwlicht in Utrecht and that it should stay forever in the use of the tertiaries of Jonge Hof: 'Venerabilis dominus Gherardus de Buren, canonicus sancti Salvatoris in Trajecto, legavit librum istum domui seu conventui sancte Marie in Weesp. Salvo que non alienetur [ab] illa domo sed sit imperpetuum usum pri(...)s ibidem in tempo' ['The venerable lord Gerard van Buren, canon of St Salvator in Utrecht, has bound this book for the house or convent of St Mary in Weesp. Store it so that it will not be stolen from this house but may it be for the infinite use of the same [...] over time'].

46 'ad usum confessoris'.

47 The incunabula in Haarlem, Stadsbibliotheek mentioned in this article have been catalogued by G.J. Jaspers, De blokboeken en incunabulen in Haarlems Libry (Haarlem 1988). The idea that Latin incunabula were used by the confessors in the cura monialium of women religious is also apparent from the extant collection from the poor clares of Bethlehem in Brussels, who fall outside the scope of this article. Nineteen out of twentythree incunabula that are preserved from this house, were according to their ownership inscriptions part of the library of the confessors (Bibliotheca confessarii). 


\section{Conclusion}

The exploration of incunabula owned by tertiaries and canonesses regular in the Low Countries indicates that the earliest printed books affected book ownership and access to texts significantly. We were able to trace no fewer than 82 incunabula from these two types of female houses only (for full details, see Appendix 1). Especially in communities of tertiaries, the incunabula traced in this article often represent a substantial increase in book ownership. The texts contained in these books were important additions to the women's library collections: some editions introduced 'new' texts (or at least new recensions of texts, such as the dialogic Boeck van den leven Jhesu Christi), while others provided texts that had already gained (some) popularity among these groups of women in manuscript form (for example Thomas of Cantimprés Bien boec). Printing, of course, eliminates the actual practice of copying of a text, which is how fifteenth-century (semi-)religious women often acquired manuscripts: they wrote their own books. Incunabula were either donated or bought, and this happened often through familial connections.

Geographically, the reception of incunabula seems to concentrate in the Northern Netherlands, but this is also the region with the highest number of the type of communities under discussion here. Incunabula, and thus the texts contained in them - travelled interregionally: books produced in Utrecht were read in Brussels, and others produced in Zwolle found their way to communities in Amsterdam, Alkmaar, and Hoorn. The market in Latin incunabula was truly international, and the Latin books that found their way to tertiaries and canonesses regular in the Low Countries were probably acquired via agents (book sellers) and through confessors, as seems to have been the case in Weesp.

Our preliminary study clearly indicates that incunabula were fully integrated into the existing book collections and reading practices rather than taking a place in the communities and their libraries at the expense of manuscripts. They were used alongside manuscripts, decorated as manuscripts, and they even influenced manuscript culture in the sense that they served as copy for manuscripts (Boeck des gulden throens). Studies into late medieval book ownership among (semi-)religious women will undoubtedly benefit from likewise integrating printed books into research, giving them the place they deserve, and allowing manuscript studies to become - at least to a certain extent - influenced by our increasing knowledge about incunabula. More data about the ownership of incunabula will help book, literary, and art historians answer questions concerning the (changing) acquisition policy of books by convent sisters after the introduction of the printing press. Thus, we can come to a more complete understanding of how communities of religious women 
enjoyed intimate and dynamic connections to the (secular) world around them, not only via familial ties, but also via active intellectual interest and cultural exchange.

\section{Appendix 1: List of Incunabula in Convents of Canonesses Regular and Tertiaries}

(After each first entry of a text or an edition thereof the ISTC-number will be mentioned).

\begin{tabular}{|c|c|c|}
\hline Canonesses regular & Edition & Repository \\
\hline Amsterdam, & Die duytsche Souter (Zwolle: Peter van & London, British Library (BL), \\
\hline \multirow[t]{2}{*}{ St Agnes? } & Os, 24 March 1491) & A. 48145 \\
\hline & (ISTC ipo10710oo) & \\
\hline \multirow{8}{*}{$\begin{array}{l}\text { Amsterdam, } \\
\text { St Catharina }\end{array}$} & Jacobus of Voragine, Legenda & Paris, BnF, RES-H-271 \\
\hline & aurea / Passionael (Winter-ende & \\
\hline & Somerstuc) (Gouda: Gerard Leeu, & \\
\hline & 1478) (ISTC ijoo139ooo) & \\
\hline & Bernardus of Clairvaux, Sermonen & London, BL, Iв.48163 \\
\hline & (Winter-ende somerstuck) & \\
\hline & (Zwolle: Peter van Os, 27 May & \\
\hline & 1495) (ISTC iboo435Ooo) & \\
\hline \multirow{4}{*}{$\begin{array}{l}\text { Amsterdam, } \\
\text { St Maria Magdalena } \\
\text { op het Spui }\end{array}$} & Otto of Passau, Dat boeck des & Louvain, Maurits \\
\hline & gulden throens (Utrecht: Printer & Sabbebibliotheek, fonds \\
\hline & with the Monogram, 30 March 148o) & Berchmanianum (shelfmark \\
\hline & (ISTC iooo1240oo) & unknown) \\
\hline \multirow{8}{*}{$\begin{array}{l}\text { Amsterdam, } \\
\text { Ter Lelie }\end{array}$} & Johannes Gerlach, Leven van & The Hague, кв, KW 169 G 85 \\
\hline & Liedwij, die maghet van Schiedam & \\
\hline & (Delft: Christiaen Snellaert, & \\
\hline & 11 June 149o) (ISTC igoo182550) & \\
\hline & Jerome, Van den leven der heiligen & The Hague, кB, KW 170 E 13 \\
\hline & vaderen (Delft: Hendrik Eckert van & \\
\hline & Homberch, before 5 April 1498) & \\
\hline & (ISTC ihoo2120oo) & \\
\hline
\end{tabular}


(cont.)

\begin{tabular}{|c|c|c|}
\hline Canonesses regular & Edition & Repository \\
\hline & $\begin{array}{l}\text { Breviarium Windeshemense } \\
\text { (Schoonhoven: Canonici Regulares } \\
\text { apud S. Michaelem in Den Hem, c. } 1 \\
\text { February 1499) (ISTC ibo11445Oo) }\end{array}$ & The Hague, кв, KW 234 F 26 \\
\hline $\begin{array}{l}\text { Beverwijk, } \\
\text { Marienborn }\end{array}$ & $\begin{array}{l}\text { Gotschalcus Hollen, Praeceptorium } \\
\text { divinae legis (Köln: Johann } \\
\text { Guldenschaff, 1484) } \\
\text { (ISTC ihoo2940oo) }\end{array}$ & Haarlem, sB, 183 B 9 \\
\hline \multirow[t]{3}{*}{$\begin{array}{l}\text { Brussels, Onze Lieve } \\
\text { Vrouw ter Rosen } \\
\text { gheplant in Jericho }\end{array}$} & $\begin{array}{l}\text { Wech der sielen salicheit (Utrecht: } \\
\text { Printer with the Monogram, } 13 \\
\text { January 1480) (ISTC iwooo10750) }\end{array}$ & Paris, BnF, D-2797 (1) \\
\hline & $\begin{array}{l}\text { Otto of Passau, Dat boeck des gulden } \\
\text { throens (Utrecht: Printer with the } \\
\text { Monogram, 30 March 1480) }\end{array}$ & Paris, BnF, D-2797 (2) \\
\hline & $\begin{array}{l}\text { Ludolph of Saxony, Boeckvan- } \\
\text { den leven ons Heeren Jesu Christi } \\
\text { (Antwerp: Geraert Leeu, 1487) } \\
\text { (ISTC iloo3530oo) }\end{array}$ & Paris, BnF, D-672 \\
\hline $\begin{array}{l}\text { Delft, St Agnes in het } \\
\text { dal van Josaphat }\end{array}$ & $\begin{array}{l}\text { Nicholas of Lyra, Postilla super } \\
\text { totam Bibliam (Strassburg: Johann } \\
\text { Mentelin, not after 1472) } \\
\text { (ISTC inoo133Ooo) }\end{array}$ & $\begin{array}{l}\text { The Hague, Kв, KW } 169 \mathrm{~A}_{3} \\
(1-2)\end{array}$ \\
\hline \multirow[t]{2}{*}{ Delft, St Anna } & $\begin{array}{l}\text { Der sielen troest (Haarlem: Jacob } \\
\text { Bellaert, } 9 \text { August 1484) } \\
\text { (ISTC isoo } 361000 \text { ) }\end{array}$ & $\begin{array}{l}\text { Wolfenbüttel, нAB, A: } 5^{23} \cdot 1 \\
\text { Theol. } 2^{\circ}(1)\end{array}$ \\
\hline & $\begin{array}{l}\text { Otto of Passau, Dat boeck des gulden } \\
\text { throens (Haarlem: Jacob Bellaert, } \\
25 \text { October 1484) } \\
\text { (ISTC iooo125000) }\end{array}$ & $\begin{array}{l}\text { Wolfenbüttel, нАв, A: } 5^{23.1} \\
\text { Theol. } 2^{\circ}(2)\end{array}$ \\
\hline $\begin{array}{l}\text { Deursen near } \\
\text { Ravenstein, } \\
\text { Soeterbeeck }\end{array}$ & $\begin{array}{l}\text { Breviarium Windeshemense (Delft: } \\
\text { Henricus Eckert van Homberch, } \\
\text { August 1499) (ISTC ibo114455O) }\end{array}$ & Nijmegen, UB, IV $5^{1}$ \\
\hline & $\begin{array}{l}\text { Book of hours ad usum Windesheim } \\
\text { (Schoonhoven: Canonici Regulares } \\
\text { apud S. Michaelem in Den Hem, date } \\
\text { unknown) }\end{array}$ & Nijmegen, U B, IV 136 \\
\hline
\end{tabular}


(cont.)

Canonesses regular Edition Repository

\begin{tabular}{|c|c|c|}
\hline $\begin{array}{l}\text { Diepenveen, St Maria } \\
\text { and St Agnes }\end{array}$ & $\begin{array}{l}\text { Petrus Berchorius, Liber bibliae } \\
\text { moralis (Deventer: Pafraet, 1477) } \\
\text { (ISTC iboo } 338 \text { ooo) }\end{array}$ & Deventer, AB, 2000 E $53 \mathrm{KL}$ \\
\hline & $\begin{array}{l}\text { Otto of Passau, Boeck des gulden } \\
\text { throens (Utrecht: Printer with the } \\
\text { Monogram, 3o March 1480) }\end{array}$ & Deventer, AB, 113 B 6 KL \\
\hline & $\begin{array}{l}\text { Jacobus of Voragine, Sermonen op } \\
\text { die evangelien van de zondagen door } \\
\text { dat gehele jaer (Zwolle: Peter van Os, } \\
6 \text { November 1489) } \\
\text { (ISTC ijoo197400) }\end{array}$ & Deventer, AB, 113 B 7 KL \\
\hline Dordrecht, St Agnes & $\begin{array}{l}\text { Ludolph of Saxony, Boeck vanden } \\
\text { leven Jhesu Christi (Antwerp: } \\
\text { Claes Leeu, } 20 \text { November 1488) } \\
\text { (ISTC iloo35500o) }\end{array}$ & Haarlem, sB, 56 E 2 \\
\hline Geldern, Nazareth & $\begin{array}{l}\text { Ludolph of Saxony, Boeck vanden } \\
\text { leven Jhesu Christi (Antwerp: Geraert } \\
\text { Leeu, } 3 \text { November 1487) }\end{array}$ & $\begin{array}{l}\text { Stuttgart, Württembergische } \\
\text { Landesbibliothek, Inc. } \\
\text { fol.10048-1 and } \\
\text { Inc.fol.10048-2 }\end{array}$ \\
\hline Gent, St Agnes & $\begin{array}{l}\text { Jacobus of Voragine, Legenda aurea / } \\
\text { Passionael (Zwolle: Peter van Os, } \\
18 \text { November } 1490(1) \text { and } 1 \\
\text { September } 1490(2))\end{array}$ & $\begin{array}{l}\text { Hiersemann } 5^{62} \\
(\text { March 1926) }\end{array}$ \\
\hline Hoorn, Bethlehem & $\begin{array}{l}\text { Jacobus of Voragine, Legenda aurea / } \\
\text { Passionael (Zwolle: Peter van Os, } \\
18 \text { November 149o) (ISTC ijoo14200o) }\end{array}$ & The Hague, KB, KW 171 E 28 \\
\hline Leiden, St Cecilia & $\begin{array}{l}\text { Biblia: Vetus Testamentum [Dutch]. } \\
\text { Without the Psalms, but includ- } \\
\text { ing the Apocrypha (Delft: Jacob } \\
\text { Jacobszoon van der Meer and } \\
\text { Mauricius Yemantszoon, 10 January } \\
\text { 1477) (ISTC iboo648ooo) }\end{array}$ & $\begin{array}{l}\text { Cambridge, UL, } \\
\text { Inc.3.E.2.1[28o9] }\end{array}$ \\
\hline
\end{tabular}

Leiden, Rapenburg Die duytsche souter (Delft: Jacob The Hague, M Mw, o01 F o13 Jacobszoon van der Meer, 12 February 1480) (ISTC ipo10700oo) 
(cont.)

Canonesses regular Edition Repository

\begin{tabular}{|c|c|c|}
\hline & $\begin{array}{l}\text { Otto of Passau, Dat boeck des gulden } \\
\text { throens (Haarlem: Jacob Bellaert, } \\
25 \text { October 1484) }\end{array}$ & Leiden, UB, 1498 B 2 \\
\hline & $\begin{array}{l}\text { Die duytsche souter (Delft: Jacob } \\
\text { Jacobszoon van der Meer or } \\
\text { Christiaen Snellaert, 1487) } \\
\text { (ISTC ipo107050o) }\end{array}$ & $\begin{array}{l}\text { Cambridge, University Library } \\
\text { (UL), Inc.6.E.2.2[2833] }\end{array}$ \\
\hline Maaseik, St Agnes & $\begin{array}{l}\text { Guilielmus Paraldus, Summa de } \\
\text { virtutibus et vitiis (Köln: Heinrich } \\
\text { Quentell, 1479) (ISTC ipooo840oo) }\end{array}$ & Oxford, BodL, Auct. 1Q 3.30 \\
\hline $\begin{array}{l}\text { Moerkerke near } \\
\text { Bruges, Sarepta }\end{array}$ & $\begin{array}{l}\text { Hugo de Prato Florido, Sermones } \\
\text { dominicales super evangelia et } \\
\text { epistolas (Zwolle: Johannes de } \\
\text { Vollenhoe, before } 20 \text { June } 1480 \text { ) }\end{array}$ & London, BL, IB.48108 \\
\hline \multirow[t]{2}{*}{$\begin{array}{l}\text { Oegstgeest near } \\
\text { Leiden, Marienpoel }\end{array}$} & $\begin{array}{l}\text { Biblia: Vetus Testamentum [Dutch]. } \\
\text { Without the Psalms, but includ- } \\
\text { ing the Apocrypha (Delft: Jacob } \\
\text { Jacobszoon van der Meer and } \\
\text { Mauricius Yemantszoon, 10 January } \\
\text { 1477) (ISTC iboo6480oo) }\end{array}$ & $\begin{array}{l}\text { Utrecht, UB, D fol } 420 \\
\text { (Rariora) }\end{array}$ \\
\hline & $\begin{array}{l}\text { Jerome, Van den leven der heiligen } \\
\text { vaderen (Gouda: Gerard Leeu, } \\
3 \text { December 1480) (ISTC ihoo210ooo) } \\
\text { Bernardus of Clairvaux, Sermonen } \\
\text { (Winter-ende somerstuck) (Zwolle: } \\
\text { Peter van Os, } 24 \text { December } 1484 \text { (1) } \\
\text { and } 30 \text { April 1485 (2)) } \\
\text { (ISTC iboo4340oo) }\end{array}$ & $\begin{array}{l}\text { Brussels, Koninklijke } \\
\text { Bibliotheek Albert I (KBR), } \\
\text { B } 1449 \\
\text { Utrecht, UB, S MAG, Rariora } \\
\text { qu } 19\end{array}$ \\
\hline The Hague, St Agnes & $\begin{array}{l}\text { Augustine, De civitate Dei (Basel: } \\
\text { Johann Amerbach, } 13 \text { February 149o) } \\
\text { (ISTC iao1244OOO) }\end{array}$ & Haarlem, sB, 183 C 9 (1) \\
\hline & $\begin{array}{l}\text { Augustine, De trinitate (Basel: Johann } \\
\text { Amerbach, 149o) (ISTC iao1345ooo) }\end{array}$ & Haarlem, sв, 183 C 9 (2) \\
\hline Utrecht, Jerusalem & $\begin{array}{l}\text { Otto of Passau, Boeck des gulden } \\
\text { throens (Utrecht: Printer with the } \\
\text { Monogram, } 30 \text { March 1480) }\end{array}$ & Utrecht, UB, E fol. 153 (1) \\
\hline
\end{tabular}


(cont.)

\begin{tabular}{lll} 
Canonesses regular & Edition & Repository \\
\hline & $\begin{array}{l}\text { Wech der sielen salicheit (Utrecht: } \\
\text { Printer with the Monogram, 1480) }\end{array}$ & Utrecht, UB, E fol. 153 (2) \\
Vudolph of Saxony, Boeck vanden & Utrecht, MCC, ABM I 13 \\
& $\begin{array}{l}\text { leven Jhesu Christi (Zwolle, Peter van } \\
\text { Os, 15 March 1499) (ISTC iloo357000) }\end{array}$ \\
\hline
\end{tabular}

\begin{tabular}{lll}
\hline Tertiaries & Edition & Repository \\
\hline
\end{tabular}

Alkmaar, Jonge Hof (?) Thomas of Cantimpré, Thussels, KBR, Inc. B 1575

Der bien boeck (Zwolle: Peter van Os,

15 January 1488)

(ISTC itoo3480oo)

Amersfoort, St Agnes Bernardus of Clairvaux, Sermonen

Groningen, UB, Inc. 40

(Winter-ende somerstuck) (Zwolle:

Peter van Os, 27 May 1495)

Amsterdam, St Barbara $\quad$ Ludolph of Saxony, Boeck vanden

Berlin, Staatliche Museen

leven Jhesu Christi (Zwolle: Peter van

zu Berlin, Kupferstich-

Os, 15 March 1499)

Kabinett, Inc 2780

Amsterdam, St Cecilia Jerome, Van den leven der heiligen

The Hague, MMW, II 110 vaderen (Gouda: Gerard Leeu,

3 December 1480)

Amsterdam, St Clara Jacobus of Voragine, Sermonen op die evangelien van de zondagen door

Oxford, BodL, Ashmole dat gehele jaer (Zwolle: Peter van Os, 6 November 1489)

Amsterdam, Souter O.L.V. (Leiden: Hugo 1768

St Margaretha Janszoon van Woerden, after 25 May 1498) (ISTC iboo4256oo)

The Hague, KB, KW 228 G 6 (2) (bound with Bonaventure, Boeck vanden vier oefeningen (Leiden: Jan Severszoon, c. 1510)) 
(cont.)

$\begin{array}{lll}\text { Tertiaries } & \text { Edition } & \text { Repository }\end{array}$

Amsterdam, Elfduizend

Maagden
Jerome, Van den leven der heiligen

vaderen (Gouda: Gerard Leeu,

3 December 1480)

Twespraec der creaturen (Gouda:

Gerard Leeu, 4 April 1481)

(ISTC idoo159550)

Otto of Passau, Dat boeck des gulden

throens (Haarlem: Jacob Bellaert,

25 October 1484)

Biblia Latina with Nicolas of Lyra,

Postillae (Nürnberg: Anton Koberger,

c. 1492)

Den Dungen near 's-Herto- Wech der sielen salicheit (Utrecht:

genbosch, Eikendonk

Enkhuizen, St Clara

Haarlem, Crayenhorst

Haarlem, St Anna

Haarlem, St Catharina
Printer with the Monogram, before

5 May 1479)

Otto of Passau, Dat boeck des gulden throens (Haarlem: Jacob Bellaert, 25 October 1484)

Thomas of Cantimpré, Der bien boeck (Zwolle: Peter van Os, 15 January 1488)

Jacobus of Voragine, Legenda aurea / Passionael (Gouda: Gerard Leeu, 1480) Tafelboec (Utrecht: Printer with the Monogram, before 5 May 1479)

Jacobus of Voragine, Legenda aurea / Passionael (Gouda: Gerard Leeu, 1480)

Boethius, De consolatione philosophiae (Gent: Arend de Keysere, 3 May 1485) (ISTC iboo81200o)
The Hague, KB, KW 170 E $26(1)$

The Hague, KB, KW 170 E 26 (2)

Copenhagen, Det

Kongelige Bibliotek, Inc.

Haun. 2975

Haarlem, SB, 168 A 2-3

The Hague, KB, KW 168

E 32

Louvain, Maurits

Sabbebibliotheek, Fonds

Berchmanianum, 6000

A 27 (1)

Louvain, Maurits

Sabbebibliotheek, Fonds

Berchmanianum, 6000

A 27 (2)

Manchester, John Rylands

Library, 19570.2

Haarlem, sB, $5^{6}$ D 19

Oxford, BodL, Auct.

III.Q.V.29

Utrecht, MCc, вмн Warm ${ }_{1126} \mathrm{H} 8$ 
(cont.)

Tertiaries

Edition

Repository

\begin{tabular}{|c|c|c|}
\hline & $\begin{array}{l}\text { Meffret, Sermones de tempore et de } \\
\text { sanctis (Basel: Nikolaus Kessler, } \\
20 \text { January 1487) (ISTC imoo4420oo) }\end{array}$ & $\begin{array}{l}\text { Utrecht, мсс, вмн Warm } \\
\text { i1263F5 }\end{array}$ \\
\hline Haarlem, Maria & Otto of Passau, Dat boeck des gulden & Oxford, BodL, Auct. 6Q \\
\hline \multirow[t]{2}{*}{ Tenhemelopneming } & $\begin{array}{l}\text { throens (Haarlem: Jacob Bellaert, } \\
25 \text { October 1484) }\end{array}$ & 5.23 \\
\hline & $\begin{array}{l}\text { Ludolph of Saxony, Boeck vanden } \\
\text { leven Jhesu Christi (Antwerp: Geraert } \\
\text { Leeu, } 3 \text { November } 1487 \text { ) }\end{array}$ & The Hague, Mmw, 1.B.2 \\
\hline Harderwijk, St Catharina & $\begin{array}{l}\text { Breviarium Traiectense (Gouda: } \\
\text { Gerard Leeu, } 13 \text { December 1483) }\end{array}$ & $\begin{array}{l}\text { The Hague, KB, KW } 150 \\
\text { E } 29\end{array}$ \\
\hline \multirow[t]{4}{*}{ Heusden, St Catharina } & $\begin{array}{l}\text { Jacobus of Voragine, Legenda } \\
\text { aurea (Köln: Conrad Winters von } \\
\text { Homberch, } 8 \text { November 1476) } \\
\text { (IsTC ijooo86ooo) }\end{array}$ & $\begin{array}{l}\text { Cambridge, UL, } \\
\text { Inc.3.A.4.15[566] }\end{array}$ \\
\hline & $\begin{array}{l}\text { Johannes Herolt, Sermones Discipuli } \\
\text { de tempore et de sanctis (Köln: Ulrich } \\
\text { Zel, } 8 \text { May 1478) (ISTC ihoo1ooooo) }\end{array}$ & $\begin{array}{l}\text { The Hague, Mмw, о03 B } \\
\text { oo8 (o1-03) }\end{array}$ \\
\hline & $\begin{array}{l}\text { Sermones sensati (Gouda: } \\
\text { Gerard Leeu, 20 February 1482) } \\
\text { (ISTC isoo472500) }\end{array}$ & $\begin{array}{l}\text { Cambridge, UL, } \\
\text { Inc.3.E.3.1[2870] }\end{array}$ \\
\hline & $\begin{array}{l}\text { Jacobus of Voragine, Sermonen op die } \\
\text { evangelien van de zondagen door dat } \\
\text { gehele jaer (Zwolle: Peter van Os, } \\
6 \text { November 1489) }\end{array}$ & $\begin{array}{l}\text { Halle, Franckesche } \\
\text { Stiftungen, } 5 \mathrm{C}_{14}\end{array}$ \\
\hline Hoorn, St Catharina & $\begin{array}{l}\text { Thomas of Cantimpré, Der bien } \\
\text { boeck (Zwolle: Peter van Os, } \\
\text { 15 January 1488) }\end{array}$ & $\begin{array}{l}\text { New Haven, Conneticut, } \\
\text { Yale University Library, } \\
\text { Beinecke } 1973^{+12}\end{array}$ \\
\hline Leiden, St Barbara (?) & $\begin{array}{l}\text { Bernardus of Clairvaux, Sermonen } \\
\text { (Winter- ende somerstuck) (Zwolle: } \\
\text { Peter van Os, } 27 \text { May 1495) }\end{array}$ & $\begin{array}{l}\text { Cambridge (Mass), } \\
\text { Harvard College Library, } \\
\text { Typ Inc } 9145\end{array}$ \\
\hline Leiden, Roomburg & $\begin{array}{l}\text { Jerome, Van den leven der heiligen } \\
\text { vaderen (Gouda: Gerard Leeu, } \\
3 \text { December } 1480 \text { ) }\end{array}$ & $\begin{array}{l}\text { Paris, Fondation Custodia, } \\
\text { oв-o.11.6 }\end{array}$ \\
\hline
\end{tabular}


(cont.)

$\begin{array}{lll}\text { Tertiaries } & \text { Edition } & \text { Repository }\end{array}$

Muiden, St Catharina

(Pseudo-)Bonaventure, Sermones

Cambridge, UL,

de tempore et de sanctis (Zwolle:

Inc.3.E.7.1.[3057]

Johannes de Vollenhoe, 1479)

Tongeren, St Agnetenberg Antonius Rampigollis and Bindo de

Senis, Aurea Biblia, sive Repertorium

The Hague, KB, KW 168

aureum Bibliorum (Köln: Johann

Guldenschaff, about 1478)

(ISTC irooo150oo)

Leonardo Mattei da Udine,

Quadragesimale: Sertum fidei

The Hague, KB, KW 171

(Deventer: Richardus Pafraet,

1479-80) (ISTC iloo14100o)

Utrecht, St Cecilia

Die duytsche Souter (Delft: Hendrik

Eckert van Homberch, 1498)

C 18

(ISTC ipo107200o)

Utrecht, St Nicolaas

Tafel des Kersteliken levens (with

The Hague, MMW, oo1 E

Antonius de Rovere: Lof van den heili-

O49 (1)

gen sacrament (Gouda: Gerard Leeu,

20 August 1478) (ISTC itooo1080o)

Spiegel des kersten gheloefs (Gouda:

Gerard Leeu, 1 September 1478)

The Hague, MMW, oor E

(ISTC isoo6720oo)

Weesp, Jonge Hof

Aelius Donatus, Ars minor (The

o49 (2)

Netherlands: Prototypography,

The Hague, KB, KW $15^{\circ}$

about 1465-80) (ISTC idoo3269oo)

Robertus Caracciolus, Sermones

C 66

quadragesimales de poenitentia

The Hague, кв, KW 169

(Köln: Ulrich Zel, 17 January 1473)

(ISTC icool710oo)

Thomas Aquinas, Summa theologiae: The Hague, KB, KW 170

secunda pars (Basel: Berthold Ruppel, A 10

not after 1474) (ISTC itoo2140oo)

Astesanus of Asti, Summa de casibus

The Hague, KB, KW 169

conscientia (Strassburg: Printer

A 24

of Henricus Ariminensis (Georg

Reyser?), not after 9 May 1474)

(ISTC iao11630oo) 
(cont.)

\begin{tabular}{|c|c|c|}
\hline Tertiaries & Edition & Repository \\
\hline & Peter Lombard, Glossa magistra- & The Hague, кв, KW 169 \\
\hline & lis Psalterii (Nuremberg: Johann & $\mathrm{A} 13$ \\
\hline & Sensenschmidt and Andreas & \\
\hline & Frisner, 12 February 1478) & \\
\hline & (ISTC ipoo477ooo) & \\
\hline & Thomas Aquinas, Opuscula (Southern & The Hague, кв, кW 171 \\
\hline & $\begin{array}{l}\text { Netherlands?: Printer of Augustinus, } \\
\text { Explanatio psalmorum, about 1488) } \\
\text { (ISTC itoo25850o) }\end{array}$ & $\mathrm{D}_{36}$ \\
\hline & Gratianus, Decretum (Basel: & The Hague, кB, KW $170 \mathrm{~F} 8$ \\
\hline & Johann Froben, 13 June 1493) & \\
\hline & (ISTC igoo3840oo) & \\
\hline & Antoninus Florentius, Summa theo- & The Hague, кв, KW 168 \\
\hline & logica (Strassburg: Johann Grüninger, & B 33 \\
\hline & 1496) (ISTC iaoo878ooo) & \\
\hline & Thomas Aquinas, Super quarto & The Hague, кв, KW 151 E 6 \\
\hline & libro Sententiarum Petri Lombardi & \\
\hline & (Venice: Bonetus Locatellus, for & \\
\hline & Octavianus Scotus, 23 May 1497) & \\
\hline & (ISTC itool720oo) & \\
\hline \multirow[t]{7}{*}{ Weesp, Oude Hof } & Aelius Donatus, Ars minor (The & The Hague, кв, кW 150 C \\
\hline & $\begin{array}{l}\text { Netherlands: Prototypography, } \\
\text { about } 1465^{-80} \text { ) (ISTC idoo32066o) }\end{array}$ & $5^{2}(1)$ \\
\hline & Aelius Donatus, Ars minor (The & The Hague, кв, кW 150 C \\
\hline & $\begin{array}{l}\text { Netherlands: Prototypography, } \\
\text { about } 1465-80 \text { ) }\end{array}$ & $5^{2}(2)$ \\
\hline & Johannes Gallensis, Summa collatio- & The Hague, KB, KW 168 \\
\hline & num (Köln: Ulrich Zel, about 1472) & $\mathrm{F}_{5}{ }^{2}$ \\
\hline & (ISTC ijoo3280oo) & \\
\hline
\end{tabular}

